\title{
Permanent Grasslands in an Anthropogenically Burdened Region, and Their Contribution to Sustainable Development
}

\author{
Jaroslava Vráblíková1, Petr Vráblík1, Eliška Wildová1, Miloslav Šoch² \\ ${ }^{1}$ Department of Natural Sciences, Faculty of Environment, J. E. Purkyně University in Ústí nad Labem, Ústí nad Labem, Czech \\ Republic \\ ${ }^{2}$ Faculty of Agriculture, University of South Bohemia in České Budějovice, České Budějovice, Czech Republic \\ Email: Wildova.Eliska@gmail.com
}

How to cite this paper: Vráblíková, J. Vráblík, P., Wildová, E. and Šoch, M. (2017) Permanent Grasslands in an Anthropogenically Burdened Region, and Their Contribution to Sustainable Development. Agricultural Sciences, 8, 816-824.

https://doi.org/10.4236/as.2017.88060

Received: July 26, 2017

Accepted: August 18, 2017

Published: August 21, 2017

Copyright $\odot 2017$ by authors and Scientific Research Publishing Inc. This work is licensed under the Creative Commons Attribution International License (CC BY 4.0).

http://creativecommons.org/licenses/by/4.0/

\begin{abstract}
The landscape of the northern part of the Czech Republic (the Chomutov, Most, Teplice and Ustí nad Labem districts) has long been burdened by the surface mining of brown coal. Within the reclamation and restoration processes, the anthropogenic formations which were created have been successfully integrated into the surrounding landscape. One of the important regional elements which have been utilized during the regeneration is permanent grasslands (PGL). They are of considerable importance not only for cattle grazing, but also for the preservation of the region's biodiversity and protection of the soil. The contribution deals with the production and non-production functions of permanent grasslands in the landscape, and their significance within the scope of the permanently sustainable development of an anthropogenically burdened region. Permanent grasslands are part of the agricultural landscape, but their significance is multifunctional, because they not only provide an environment for cattle grazing, but also protect soil, the nutrient cycle and the microclimate, and preserve biodiversity. At the same time, the article analyzes in detail the development of this vegetation in the area of interest-Northern Bohemia. During the period of the greatest mining boom (1967-1990), its rapid decrease-by as much as 4500 ha-was recorded in some areas. Since the year 1990, there has been a significant growth in the most damaged areas. At present, the development of PGLs has stabilized.
\end{abstract}

\section{Keywords}

Soil land Use, Agricultural Land, Permanent Grasslands, Sustainable

Development, Northern Bohemia 


\section{Introduction}

The character of the landscape is the result of the activity and joint effect of natural and human factors. The target quality of the landscape means an expression of the people's requirements and wishes regarding the character of the environment they live in, formulated for the given region by competent public authorities. By protecting the landscape, we aim to preserve and maintain its distinctive or characteristic properties, formed by natural configurations and human activity, and rightfully regarded as its historical value. When planning the landscape, we purposefully focus our activities on improving its quality, and on its regeneration or creation [1]. In order for the region to be defined as sustainable and therefore be preserved for future generations, its development must be governed not only by ecological and environmental aspects, but also by economic and social ones. The region of Northern Bohemia, particularly the Chomutov, Most, Teplice and Ústí nad Labem districts, has been affected by the intensive surface mining of brown coal for almost 200 years. At the beginning, the direction of this anthropogenically burdened region was of a purely economic nature, but with the change of political regime and society's thinking, ecological and social points of view also gradually began to be applied, thanks to reclamation and restoration processes. Thanks to this, the area has considerable potential for the formation of a new landscape, which is governed by the principle of sustainable development.

In order for the newly formed area to be able to integrate into the existing landscape, its creation must be approached with a view to increasing biodiversity. Grasslands are versatile ecosystems, generating a diverse array of goods and services that are useful to humankind. It is widely recognized that grasslands support high quality livestock produce, chiefly from ruminants. By maximizing pastures as the primary diet, grasslands provide alternatives to concentrate feed. This reduces the inefficient use of arable land. Grasslands provide critical ecosystems services that regulate, support and underpin the environment that we live in. These include climate regulation, water storage, nutrient cycles, erosion control, pollination and biodiversity. Despite their multiple functions, the potential role of grasslands in addressing environmental and food security challenges is often poorly understood and under-valued. The contributions of grasslands, permanent pastures, forage crops and crop residues (for integrated systems) are ignored. There is an urgent need to recognize and add value to the multiple ecological functions of grasslands before large areas of this vital resource are degraded or diverted into agricultural land. An important goal is to raise awareness about the potential of sustainable grassland management to achieve positive outcomes for the environment, people and economies [2].

\section{Materials and Methods}

\section{Permanent Grasslands and Their Functions in the Landscape}

Grasslands, as a complex mixed and overall very diverse community of grasses, 
clovers and other herbaceous species, represent an important component of the plant part of the biosphere. At the same time, on a global scale, it is one of the most widespread biomes ever. Their area across the entire globe is almost $30,000,000 \mathrm{~km}^{2}$, which represents twice the area of arable land. In the Czech Republic, the area of grasslands is currently 998 thousands ha.

Since the 19th century, as a result of extensive sociological-economic changes across the whole of society, there have also been significant changes in the landscape. Over two centuries, there has been extensive industrialization, coal mining, depopulation of border areas, land consolidation, chemical treatment and drainage of agricultural land, as well as urban changes. The development of society and extensive changes in the landscape has also brought about changes in the utilization of permanent grasslands. Now it is not just their production function which is important; non-production functions are also becoming increasingly important. In a disrupted and unstable landscape, grasslands fulfill anti-erosion, water protection, filtration, flood protection, microclimatic, diversity protection, landscape-forming, leisure and aesthetic functions. Therefore, the importance of grasslands is growing, along with the need to deal with the negative impact of civilization on the environment. At present, the non-production functions of grasslands may be becoming more important than their production functions. Nevertheless, one cannot but see the rapid growth in the population of the entire planet, and we can expect the pressure on the productive utilization of agricultural land to rise continuously, not only around the world but also in Europe. That is why one of the methods of caring for soil is to grass it over, which enables its fast return to food production. One might say that grasslands now have an added strategic-preservation function, in protecting and facilitating the preservation of the fertility of arable land.

The effect of grasslands on the hydrosphere lies mainly in the retention of rainwater. This guarantees the supply of groundwater, which has extraordinary significance under our conditions, where water sources are limited and water is flowing out of our region [3]. Well-connected grasslands capture water which flows away over the surface from higher-lying arable land after torrential rains, reduce flow velocity, support sedimentation, and increase the proportion of water absorbed into the soil [4].

Well-connected vegetation, a dense vegetation cover and a rich grassland root system fundamentally affect a wide range of soil properties. Grasslands enrich the soil with a large amount of organic matter, release nutrients from less accessible bonds, enrich the soil with symbiotically fixed airborne nitrogen, take nutrients and water from the soil, protect soil against drought and solar radiation, and significantly reduce its erosion by water and air. Protection against erosion, in particular, is very important [5].

Grasslands significantly affect the gas exchange and element cycles in the photosynthesis process, whereby they release oxygen using carbon dioxide and water, and store the oxygen in biomass. Through symbiotic bacteria on clov- 
er-type plants, they also influence the nitrogen cycle [6].

The effect of grasslands on the preservation of biodiversity is crucial. Natural meadow vegetation is mostly composed of 30 - 70 species of higher plants, and the number of species of microorganisms, lower plants and animals, especially insects and phytophagous invertebrates, is usually considerably higher. Therefore, grasslands are an enormous source of genetic information stored in the genotypes of plant and animal species, and soil microorganisms. In the interaction with various methods and intensities of farming, various types of vegetation show considerable differences in the biodiversity of plant and animal species. MLÁDEK et al. (2006) [4] state that the large species diversity of grassland fauna is mostly the result of traditional agricultural methods, which maintained diverse conditions both at a regional level and on a small scale. Thus, at present, we must support farming methods which maintain mosaicism not only at a regional level, but also in specific meadows or pasture lands.

Permanent grasslands have a strong landscape-forming function in the region, which is given by the alternation of various cultures (forests, grasslands, arable land, boundaries, orchards etc.) [5]. The human need for the recreational use of nature, and the direct contact between man and nature connected with it, is constantly growing [7]. Farmed grasslands help to create a colorful residential cultural region, rich in species, genetically diverse and with the opportunity for the growth and development of all living organisms. Diversity is then also connected with the aesthetic function. The production function of grasslands is directly related to the production of dietetically valuable fodder and health of farm animals, the high quality of animal products, and as a result also human health.

There is a positive correlation between the intensity of use of permanent grasslands in submontane and mountain areas and their optimal productive application, which is also present between their production and non-production functions. At an appropriate intensity of use, the quality of the harvested biomass increases, as well as species colorfulness and the diversity of the vegetation. Other ecological functions of the grasslands in the region also improve (water evaporation and temperature gradient above the vegetation, quality of soil organic matter, groundwater quality etc.)

\section{Results and Discussion}

PGLs are a part of agricultural land. The agricultural land in the model area recorded a more extensive occupation from the year 1967 to the year 1990 as a result of increased mining activity; since that time, the depletion has not been as radical, and we can say that the year-on-year values to the present day have been approximately the same. In the Chomutov district, a more noticeable depletion was observed during the period of occupation of agricultural land in comparison with other districts in the area of interest. In the Czech Republic, the developmental trend of agricultural land measurement was similar to that in the Chomutov district, but the agricultural land fund in the Czech Republic is still being 
occupied today. Since the year 2000, the area of agricultural land in the Czech Republic has been decreasing continuously, by an average of 5,000 ha annually. In the area of interest, there is a characteristically lower representation of agricultural land (38\%) compared to the national average (53.4\%), whereby the least agricultural land within the scope of the model area is found in the Most district (15.4\%), while, on the other hand, the most is found in the Chomutov district (45\%). Overall, in terms of the share of agricultural land in the total area, the Ústí nad Labem region is approaching the national average (51.6\%). Permanent grasslands cover $15.9 \%$ of the surface of the area of interest. Over 14 thousand hectares of grassland are found in the Chomutov district, but the greatest proportion of PGLs is in the Ustí nad Labem district, where they occupy a total of $30 \%$ of the district. The fewest grasslands are in the Most district (3056 ha), where they occupy only $6.5 \%$ of the area. This is due to the fact that the main surface coal mining areas are found in the territory of the Most district. Within the scope of the entire Czech Republic, PGLs take up 12.7 percent of the total area (Table 1).

\subsection{Utilization of Agricultural Land in the Model Area}

In the model area, arable land, which is used for the cultivation of agricultural crops, represents $52 \%$ of agricultural land. In second place are permanent grasslands (42\%), used mainly for grazing farm animals (Figure 1). For example, since the year 2000, the number of sheep in the Ustí nad Labem region has increased from the original 6121 to a total number of 16,002 .

The newly created grasslands in the model area will be used for grazing. The proportion of gardens- $4 \%$ and fruit orchards- $2 \%$ is already noticeably lower. Hop fields and vineyards are not highly represented in the model area (forming only $2 \%$ of the territory) because the suitable soil and climatic conditions are not

Table 1. Structure of the soil fund in the model area as of 1. 1.2017 [ha].

\begin{tabular}{cccccccc}
\hline District & $\begin{array}{c}\text { Agricultural } \\
\text { land }\end{array}$ & $\begin{array}{c}\text { Permanent } \\
\text { grasslands }\end{array}$ & Forest land & $\begin{array}{c}\text { Water } \\
\text { areas }\end{array}$ & $\begin{array}{c}\text { Built-up } \\
\text { areas }\end{array}$ & $\begin{array}{c}\text { Other } \\
\text { areas }\end{array}$ & Area in total \\
\hline Chomutov & 38,835 & 14,446 & 35,867 & 3100 & 1253 & 14,514 & 93,569 \\
Most & 13,358 & 3056 & 16,096 & 984 & 824 & 15,448 & 46,710 \\
Teplice & 16,152 & 6488 & 18,146 & 837 & 1030 & 10,727 & 46,892 \\
Ústí n.L. & 18,144 & 12,171 & 12,956 & 1027 & 905 & 7441 & 40,474 \\
MA in total & 86,489 & 36,161 & 83,065 & 5948 & 4012 & 48,130 & 227,645 \\
MA (\%) & $\mathbf{3 8 . 0}$ & 15.9 & 36.5 & 2.6 & 1.8 & 21.1 & 100.0 \\
Ustí region & 275,109 & 73,297 & 163,166 & 10,409 & 9352 & 75,818 & 533,854 \\
UR (\%) & $\mathbf{5 1 . 5}$ & 13.7 & 30.6 & 1.9 & 1.8 & 14.2 & 100.0 \\
CR in total & $4,208,374$ & $1,003,393$ & $2,669,850$ & 165,876 & 132,217 & 710,724 & $7,887,041$ \\
CR (\%) & $\mathbf{5 3 . 4}$ & $\mathbf{1 2 . 7}$ & $\mathbf{3 3 . 9}$ & $\mathbf{2 . 1}$ & $\mathbf{1 . 7}$ & $\mathbf{9 . 0}$ & $\mathbf{1 0 0 0}$ \\
\hline
\end{tabular}

MA: model area; CR: Czech Republic. Source: Own calculations from [8]. 


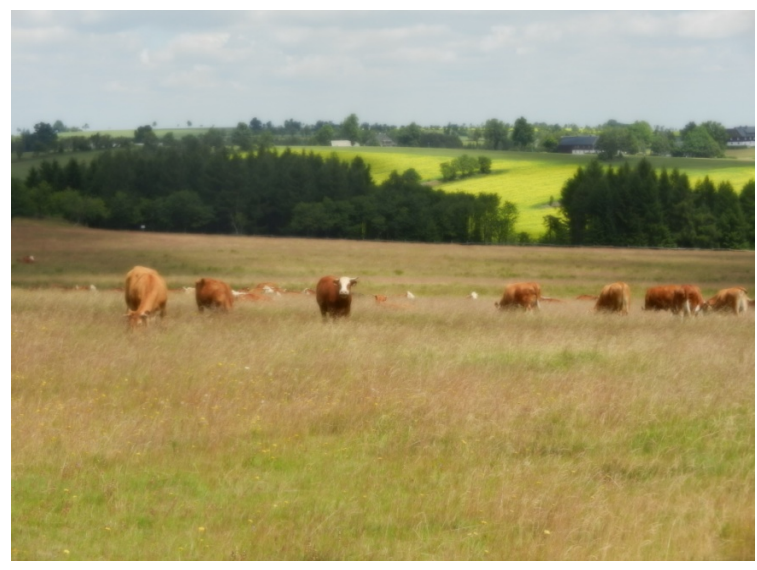

Figure 1. Cattle grazing in Fojtovice (Teplice district) [9].

present here (Figure 2). Nevertheless, reclaimed dumps have a definite potential in this regard, as the terrain can be modified so that vineyards can be more widespread here, which simultaneously supports the region's economy and its attractiveness.

\subsection{Development of PGLs in the Model Area}

One of the important aspects of permanent sustainability is the preservation of ecosystem biodiversity, whether natural or man-made. Meadows and pasture land, now referred to as permanent grasslands, have been an important element in the preservation of the cultural landscape since time immemorial. Permanent grasslands help protect biodiversity, and can represent a considerable profit for the farmer. They are therefore a valuable resource, both for the environment and for the economy. Until the year 1995, meadows and pasture land in the model area, but also in the Czech Republic, were not assigned a deeper meaning than the grazing of farm animals. However, greater emphasis on environmental protection and the sustainability of the region resulted in a rapid increase of the area of PGLs, particularly in the Chomutov and Ústí nad Labem districts, where there is a marked difference in comparison with the year 1967 (the Chomutov district by approximately 4500 ha, the Ustí nad Labem district by 2500 ha). Until the present day, a slight annual increase in the order of tens of hectares has been recorded (Figure 3). There has been a slight decrease in the area of PGLs in the Teplice district, by 95 ha. The same increasing trend in the area of PGLs is also being observed within the scope of the entire Czech Republic (Figure 4).

\subsection{The Contribution of Permanent Grasslands to Sustainability}

Under our conditions, grasslands are one of the most stable ecosystems in the agricultural landscape, and an important component of the biosphere. They have an extensive ability to relocate chemical elements, and also fulfill agricultural and non-production functions, which are important for the formation and protection of the landscape, and its biodiversity. Their productive mission is 


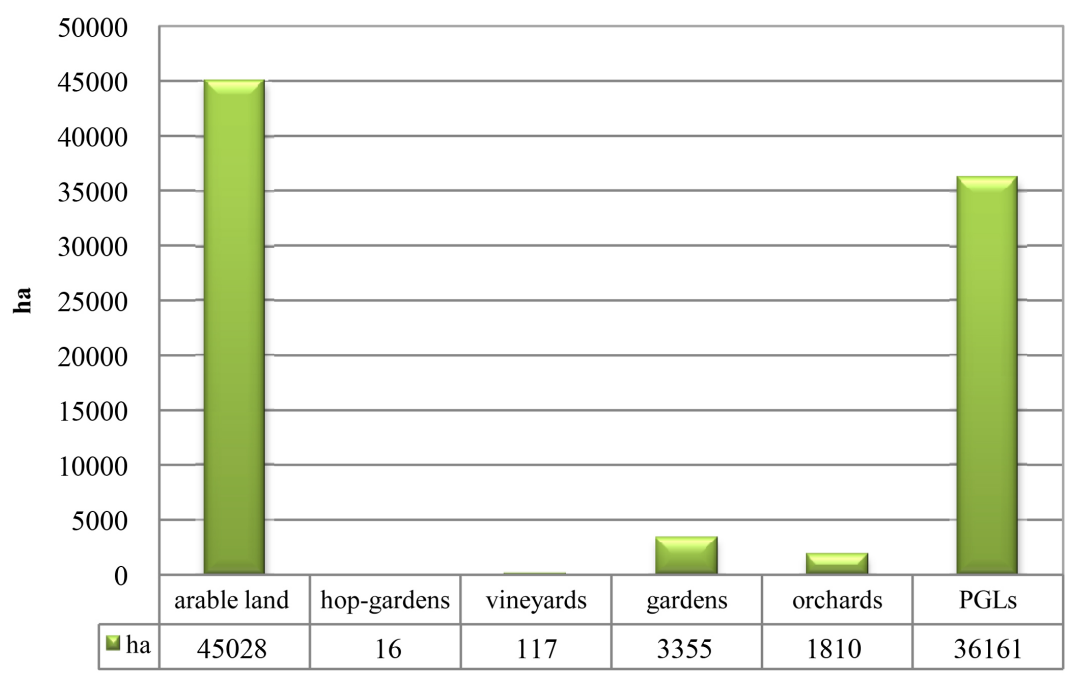

Figure 2. Use of arable land in the model area as of 1. 1. 2017 [ha]. Source: Own calculations from [8].

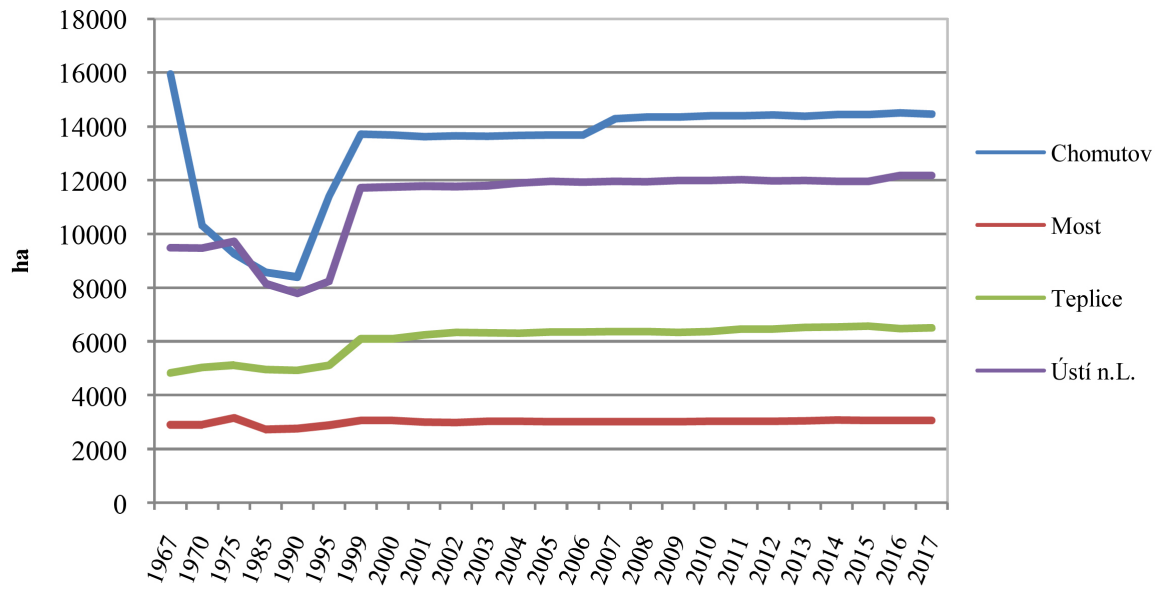

Figure 3. Development of PGLs in individual districts of the model area 1967-2017. Source: Own calculations from [8].
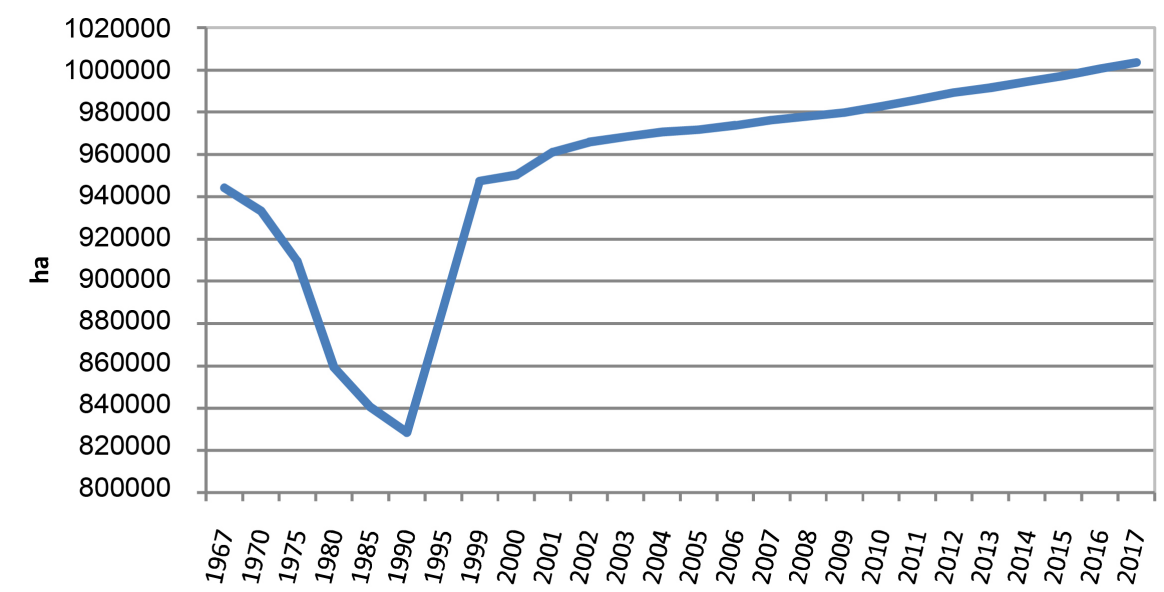

Figure 4. Development of PGLs in the Czech Rebulic 1967-2017. Source: Own calculations from [8]. 
applied directly, as a source of biomass used to feed polygastric animals, or indirectly as a source of organic substances which, after passing through an animal's digestive tract, become precursors of humus in the form of animal fertilizers. The non-production functions of grasslands have been becoming increasingly important in recent years, particularly in the context of the disruption of the biological cycles and hydrological conditions in the landscape, decreasing biodiversity, and deteriorating soil conditions [10]. For example, grasslands can affect the protection and stabilization of biodiversity, and the gene pool of animals, plants and soil microorganisms. They have a strong anti-erosion effect and function as a biological filter, they create an extensive supply of aboveground and underground active and dead organic matter connected with significant biological activity in these grasslands, they have the ability to bind to atmospheric nitrogen and some gaseous emissions, produce oxygen and reduce noise and dust, and they have the ability to capture as much as $80 \%-90 \%$ of rainwater, and possibly even retain it in the longer term as water reserves for dry periods. This is also connected with their influence on climatic conditions in the form of the release of water vapors into the air. The aesthetic function of grasslands, arising from their species diversity, long vegetative period and the natural manner in which they are formed, is also extremely important. The most natural and at the same time gentle method is to utilize them for grazing farm animals. However, the species specificities of the grazing animals must be respected, so that the grazed land is not damaged instead. Likewise, pasture lands must not be burdened with large numbers of animals or by long-term use, and the grazed areas must be agrotechnically treated after the grazing has finished. The combined use of grasslands appropriately supports the positive and limits the negative effects of their unilateral use for mowing or grazing. By appropriately alternating grazing and mowing, it is possible to influence the composition of the desired vegetation.

\section{Conclusion}

Permanent grasslands fulfill important production and non-production functions in the landscape. Not only do they form an environment for cattle grazing, they also protect the area against erosion and floods, and help to maintain the ecosystem's biodiversity. The region of Northern Bohemia has long been burdened by the surface mining of brown coal, but the anthropogenic formations which were created are a suitable environment for the emergence of a new agricultural landscape in this area, of which PGLs are an important part. Through the revitalization and recultivation processes, it is possible to directly influence the development of the landscape within the scope of the larger territory. If the principle of permanently sustainable development is adhered to, then the anthropogenically burdened territory of Northern Bohemia has considerable potential for the creation of a stable region which will also serve future generations. 


\section{Acknowledgements}

This article was supported by project QJ1520307 entitled "Sustainable Forms of Management in an Anthropogenically Burdened Region". This project was realized with financial support from state budget resources through the KUS program, Ministry of Agriculture of the Czech Republic.

\section{References}

[1] Council of Europe (2000) European Landscape Convention, Florence 20. 10. 2000. European Treaty Series, No. 176. 7 p.

[2] Food and Agriculture Organization of the United Nations (2017) Sustainable Grasslands-Working Paper. E-Conference 2-3 September 2013. 15 p.

[3] ŠANTRŮČEK, J., et al. (2001) Fundamentals of Forage Farming. Faculty of Agronomy, Czech University for Agriculture, Prague, 146 p.

[4] Mládek, J., Pavlů, V., Hejcman, M. and Gaisler, J., Eds. (2006) Pasture as a Means of Maintaining Permanent Grassland in Protected Areas. Prague, 104 p.

[5] Skládanka, J., Večerek, M. and Vyskočil, I. (2010) Grass Ecosystems. http://web2.mendelu.cz/af_222_multitext/trek/

[6] Ripl, W., Ridgill, S. C., Eiseltová, M. and Pokorný, J. (1997) Energy, Water and Matter flow in Landscape-The Key to Sustainable Land Use. In: Němec, J., Ed., Landscaping Programs-Proceedings from International Conference, Př́bram 4. 6. 11, 259-268.

[7] Jirků, Š. (2012) Visualization of Post-Mining Landscape. Diploma Thesis, Czech University for Agriculture, Prague, $62 \mathrm{p}$.

[8] Czech Office for Surveying and Cadastre (2017) Summarized Survey of Land Fund from Land Cadastre Data of the Czech Republic. Prague, 80 p.

[9] Vráblík, P. (2017) Cattle Grazing in Fojtovice (Teplice District). Author’s Own Photography.

[10] Klimeš, F. (1997) Meadows and Pastures-Grasslands Ecology. Faculty for Agriculture, University of South Bohemia in České Budějovice, $142 \mathrm{p}$ 
Submit or recommend next manuscript to SCIRP and we will provide best service for you:

Accepting pre-submission inquiries through Email, Facebook, LinkedIn, Twitter, etc. A wide selection of journals (inclusive of 9 subjects, more than 200 journals)

Providing 24-hour high-quality service

User-friendly online submission system

Fair and swift peer-review system

Efficient typesetting and proofreading procedure

Display of the result of downloads and visits, as well as the number of cited articles Maximum dissemination of your research work

Submit your manuscript at: http://papersubmission.scirp.org/

Or contact as@scirp.org 